\title{
ASSESSING THE EFFECT OF STERILIZATION ON THE RADIOCARBON SIGNATURE OF FRESHWATER DISSOLVED ORGANIC CARBON
}

\author{
Andy Baker ${ }^{1}$ Pauline Gulliver ${ }^{2} \cdot$ Phillipa Ascough $^{3} \cdot$ Jessie Roe $^{4,5} \cdot$ John Bridgeman $^{4}$ \\ ABSTRACT. Radiocarbon analysis of freshwater dissolved organic carbon (DOC) involves substantial sample pretreatment, \\ including an initial rotary evaporation stage necessary to concentrate large volumes of freshwater sample. This may lead to \\ a health risk from the exposure to pathogens, and there is the additional concern that the warm conditions during the rotary \\ evaporation stage may provide ideal growing conditions for some pathogens. To remove any pathogen risk in water samples, \\ boiling or autoclaving can be undertaken. However, to date, no studies have been undertaken to investigate whether boiling \\ will alter the ${ }^{14} \mathrm{C}$ signature of dissolved organic carbon. Here, we analyze the effect of sterilization on 9 contrasting river water \\ samples. Comparing filtered, filtered and boiled, and filtered and sterilized dissolved organic matter, we observe that both \\ boiling and autoclaving increases the uncertainty associated with the ${ }^{14} \mathrm{C}$ and ${ }^{13} \mathrm{C}$ of $\mathrm{DOC}$, that the ${ }^{14} \mathrm{C}$ and ${ }^{13} \mathrm{C}$ changes are \\ not unidirectional, and that they are not related to original DOC composition. Neither sterilization method is recommended \\ unless essential, in which instance we recommend a $3 \sigma$ uncertainty on ${ }^{14} \mathrm{C}$ and that the ${ }^{13} \mathrm{C}$ is not considered representative \\ of the original sample.
}

\section{INTRODUCTION}

Freshwater dissolved organic carbon (DOC) export is an important component of the global terrestrial carbon balance, and in many regions it is apparently increasing (Worrall and Burt 2007). It has also been demonstrated that freshwater systems do not simply act as conduits between land and ocean, but are active zones of dissolved organic matter cycling through biological processing (Battin et al. 2008, 2009), photodegradation (Cory et al. 2007), freezing and dehydration (Hudson et al. 2009), and physical processes such as colloid formation and particle settling (Battin et al. 2008; Aiken et al. 2011). For example, studies have shown high $\mathrm{CO}_{2}$ degassing from large rivers (Cole and Caraco 2001). Diurnal fluorescence cycles in a Californian agricultural stream (Spencer et al. 2007) suggest significant DOC processing over short time periods. Billett et al. (2007) and Billett and Moore (2008) have shown that peat headwater streams are hotspots for $\mathrm{CO}_{2}$ release. The recognition of the relative lability of dissolved organic matter in freshwater systems has therefore led to the increased interest in the use of radiocarbon analyses to understand the relative age and processing of DOC (Evans et al. 2007; Tipping et al. 2010). Typical results show that, in most rivers, DOC age is very young (often $>100 \%$ modern carbon) (Raymond et al. 2007) and therefore has undergone significant in-river processing (Pollard and Ducklow 2011).

${ }^{14} \mathrm{C}$ analysis of freshwater DOC involves substantial sample pretreatment, including an initial rotary evaporation stage necessary to concentrate large volumes of freshwater sample $(500 \mathrm{~mL}$ to $5 \mathrm{~L})$ with an organic carbon concentration of $1-10 \mathrm{mg} \mathrm{L}^{-1}$. A previous study by Gulliver et al. (2010) has shown that processing of replicate $(n=5)$ untreated DOC samples returns results that are internally within $1 \sigma$ confidence limits. Handling of freshwater samples may lead to a health risk from the exposure to pathogens, both from urban water samples where pathogens may derive from cross-connected sewers (untreated sewage) and sewer outfalls, and rural water samples where pathogens are more likely to derive from animal fecal material and septic tank failures. There is the additional con-

\footnotetext{
${ }^{1}$ Connected Waters Initiative Research Centre, University of New South Wales, 110 King St, Manly Vale 2093, Australia. Also: National Centre for Groundwater Research and Training. Corresponding author. Email: a.baker@unsw.edu.au.

${ }^{2}$ NERC Radiocarbon Facility (Environment), SUERC, Rankine Avenue, Scottish Enterprise Technology Park, East Kilbride G75 0QF, United Kingdom.

${ }^{3}$ SUERC, Rankine Avenue, Scottish Enterprise Technology Park, East Kilbride G75 0QF, United Kingdom.

${ }^{4}$ Civil Engineering, University of Birmingham, Edgbaston, Birmingham B15 2TT, United Kingdom.

${ }^{5}$ Severn Trent Water Ltd, Severn Trent Centre, PO Box 5309, Coventry CV3 9FH, United Kingdom.
} 
cern that the warm $\left(40{ }^{\circ} \mathrm{C}\right)$, wet conditions during the rotary evaporation stage may provide ideal growing conditions for some pathogens. Although pathogens may in part be removed by filtration at the $0.1-0.2 \mu \mathrm{m}$ range, filter sizes often used to produce a dissolved organic matter fraction, complete removal will not occur, especially of the smallest pathogens (e.g. viruses). To remove any pathogen risk in water samples, they are often sterilized by either boiling or autoclaving. However, to date, no research has been undertaken to investigate whether these sterilization procedures will alter the ${ }^{14} \mathrm{C}$ signature of dissolved organic carbon. Therefore, the aim of this paper is to assess whether different sterilization procedures change the ${ }^{14} \mathrm{C}$ signature of DOC. We will also undertake the analysis of DOC from contrasting catchments in order to investigate if boiling has different effects on DOC of different character. We hypothesize that DOC that is younger in apparent ${ }^{14} \mathrm{C}$ age (e.g. $>100 \%$ pMC) will comprise more recently produced DOC that is more labile and more susceptible to boiling than old DOC that is more recalcitrant. Given the potential lability of DOC, the operational need to sterilize freshwater samples might introduce a bias in the reported ${ }^{14} \mathrm{C}$ age, likely to indicate an older age if the labile DOC fraction is thought to be more recently processed and ${ }^{14} \mathrm{C}$ "young." Furthermore, although boiling will denature but not destroy genetic and enzymatic material, it will cause cell lysis and thus allow the cell contents to dissolve in the water column directly as well as desorption of previously stable and fine colloid $(<0.7 \mu \mathrm{m})$ bound organic matter. For example, we hypothesize that "hot water extraction" (at $150^{\circ} \mathrm{C}$ ) utilized in the soil science community to desorb organic matter from soil solutions (Schwesig et al. 1999) will also desorb organic matter from the fine colloidal fraction of water samples (see below; Wilkinson et al. 1999). The amount of material desorbed has been shown to relate to the initial hydrophobicity, with more hydrophobic material resisting extraction and remaining in the fine colloidal and dissolved fractions (Kalbitz et al. 2005). This freshly desorbed and destabilized material, together with any labile dissolved organic matter, lysed cells, etc. may be rapidly metabolized or photolysed, producing $\mathrm{CO}_{2}$ (Cole et al. 2007; Aufdenkampe et al. 2011). No studies have been undertaken on the effects of boiling or autoclaving on the ${ }^{14} \mathrm{C}$ of freshwater DOC; a necessary step before sterilization by either protocol is introduced as a standard procedure.

\section{METHODS}

Both sterilized and non-sterilized samples were analyzed, and in order to conform to Health and Safety protocols at NERC Radiocarbon Facility (Environment) where the samples were processed, we analyzed DOC at sites where all pathogen risks are minimized: 3 impounding reservoirs that serve water treatment works and the tributaries feeding those reservoirs (Table 1). The selected sites have highly managed rural catchments, with pathogen risk minimized through the prevention of livestock grazing close to any water bodies. DOC character is well understood, as spectrophotometric characterization (Bieroza et al. 2009) and disinfectant byproduct formation and organic matter character (Roe et al. 2009) of DOC reservoir outlet water at these sites over the period 2007-2008 has been undertaken as part of a wider study of organic matter character. Furthermore, sampling tributary rivers supplying contrasting drinking water reservoirs, as well as the reservoir outlet, will yield riverine DOC, which is dominated by allochthonous DOC, and reservoir DOC, which is more likely to be dominated by autochthonous DOC. Analysis of the reservoir DOC will also allow our results to be relevant to investigations of lake water DOC, which may have relevance for paleolimnological ${ }^{14} \mathrm{C}$ investigations. The mean residence time of water in each reservoir is known for each site.

Water samples for each site were obtained in July and August 2009. At each site, three 2-L samples were collected for ${ }^{14} \mathrm{C}$ analysis, together with additional samples for DOC characterization (see below). All samples were collected in precleaned polycarbonate bottles and filtered using precleaned $0.7-\mu \mathrm{m}$ Whatman GF/F glass microfiber filters. One sample was analyzed unsterilized at the 
Table 1 Sample descriptions.

\begin{tabular}{|c|c|c|c|c|}
\hline Sample site & Sample code & Catchment characteristics $^{\mathrm{a}}$ & $\begin{array}{l}\text { DOC } \\
\text { conc. } \\
(\mathrm{mg} / \mathrm{L})^{\mathrm{b}}\end{array}$ & DOC characteristics ${ }^{\mathrm{c}}$ \\
\hline $\begin{array}{l}\text { A. } \\
\text { (Bieroza et } \\
\text { al. 2009, } \\
\text { site 10) }\end{array}$ & $\begin{array}{l}\text { FR - Reservoir outlet } \\
\text { SHR - Reservoir outlet } \\
\text { RivW - input river }\end{array}$ & $\begin{array}{l}\text { Arable and pasture land } \\
\text { cover, lowland site; } \\
\text { FR: retention time } 103 \\
\text { days. SHR: retention time } \\
65 \text { days. }\end{array}$ & $4.2 \pm 0.7$ & $\begin{array}{l}\text { Intermediate hydropho- } \\
\text { bicity and aromatic } \\
\text { amino acid content. }\end{array}$ \\
\hline $\begin{array}{l}\text { B. } \\
\text { (Bieroza et } \\
\text { al. 2009, } \\
\text { site 16) }\end{array}$ & $\begin{array}{l}\text { SUR - Reservoir outlet } \\
\text { SLR - Reservoir outlet }\end{array}$ & $\begin{array}{l}\text { Pasture land cover, with } \\
\text { some forest, lowland site; } \\
\text { SUR: retention time }<2 \\
\text { days. SLR: retention time } \\
90 \text { days. }\end{array}$ & $6.7 \pm 1.2$ & $\begin{array}{l}\text { Hydrophilic, low mo- } \\
\text { lecular weight colorless } \\
\text { NOM, low/no charge } \\
\text { density, high aromatic } \\
\text { amino acid content, lit- } \\
\text { tle seasonal variation. }\end{array}$ \\
\hline $\begin{array}{l}\text { C. } \\
\text { (Bieroza et } \\
\text { al. 2009, } \\
\text { site 14) }\end{array}$ & $\begin{array}{l}\text { RivD - input river } \\
\text { HR - Reservoir outlet } \\
\text { DR - Reservoir outlet } \\
\text { LR - Reservoir outlet }\end{array}$ & $\begin{array}{l}\text { Upland peaty moorland, } \\
\text { thick organic-rich soils. } \\
\text { Three reservoirs in series; } \\
\text { water retention times in- } \\
\text { crease from } 45 \text { days (HR) to } \\
94 \text { days (DR) and } 235 \text { days } \\
\text { (LR). }\end{array}$ & $5.6 \pm 1.6$ & $\begin{array}{l}\text { Hydrophobic, high mo- } \\
\text { lecular weight and } \\
\text { charge density, colored } \\
\text { natural organic matter, } \\
\text { low aromatic amino } \\
\text { acid content, highly } \\
\text { susceptible to seasonal } \\
\text { variations. }\end{array}$ \\
\hline
\end{tabular}

${ }^{a}$ Catchment land cover from Bieroza et al. (2009). Reservoir retention times are theoretical values.

bMean and standard deviation of 12 monthly samples taken from water treatment works intakes (Bieroza et al. 2009).

${ }^{\mathrm{c}}$ Derived from fluorescence properties (Bieroza et al. 2009) and resin extractions (Roe et al. 2009).

${ }^{14} \mathrm{C}$ facility, one after an 18 -min autoclave (sample bottle remaining closed) and one after a 3-min rolling boil (sample transferred to a precleaned 5-L glass beaker, covered with a glass petri dish). Steam sterilization (autoclaving) at $134{ }^{\circ} \mathrm{C}$ for at least $18 \mathrm{~min}$ will inactivate all fungi, bacteria, viruses, and also bacterial spores. Steam sterilization might be adopted as a standard protocol for contaminated water samples, e.g. urban rivers, or for ${ }^{14} \mathrm{C}$ samples that could be submitted from research centers where autoclave facilities were available. Autoclaving also maintains a closed sample, potentially limiting the loss of volatile organic carbon. Boiling kills most vegetative bacterial and viral pathogens and would potentially be suitable protocol for sterilizing ${ }^{14} \mathrm{C}$ samples submitted directly from remote field sites. Boiling for at least $1 \mathrm{~min}$ is the US Environmental Protection Agency Emergency disinfection protocol and a 3-min boil is the current UK NERC Radiocarbon Facility (Environment) disinfection protocol.

All glassware used in the preparation of DOC samples for ${ }^{13} \mathrm{C}$ and ${ }^{14} \mathrm{C}$ analysis was cleaned overnight in $5 \mathrm{M}$ nitric acid prior to use; weighing boats and spatulas were cleaned in an oven at $450{ }^{\circ} \mathrm{C}$ for $2 \mathrm{hr}$. The $\mathrm{pH}$ probe used to monitor sample $\mathrm{pH}$ during sample pretreatment was rinsed thoroughly with deionized water between samples. Samples were first acidified to $\mathrm{pH} 4$ by drop-wise addition of $2 \mathrm{M} \mathrm{HCl}$, sparged with high-purity $\mathrm{N}_{2}$, then neutralized to $\mathrm{pH} 7$ by addition of freshly prepared $1 \mathrm{M} \mathrm{KOH}$ solution (prepared with boiled, $\mathrm{N}_{2}$-purged deionized water). A measured volume of sample was rotary evaporated, until a few $\mathrm{mL}$ of solution remained, which was quantitatively transferred to a beaker and freeze-dried. For isotope analysis, the total carbon in a known weight of the resultant solid was weighed into a tin capsule and sample carbon was recovered as cryogenically purified $\mathrm{CO}_{2}$ following combustion at $1020{ }^{\circ} \mathrm{C}$ using a Costech ECS 4010 Elemental Combustion System. Sample $\mathrm{CO}_{2}$ was converted to graphite by $\mathrm{Fe} / \mathrm{Zn}$ reduction and the resultant graphite analyzed for ${ }^{14} \mathrm{C}$ content at the Scottish Universities Environmental Research Centre (SUERC) AMS laboratory (Freeman et al. 2007, 2010). For ${ }^{13} \mathrm{C}$ analysis, this procedure was repeated for each sam- 
ple and the resultant $\mathrm{CO}_{2}$ analyzed using a duel-inlet IRMS. Analytical precision of these analyses is quoted at $\pm 0.1 \%$.

Additional DOC characterization was undertaken by spectrophotometric analyses (UV-VIS absorbance and fluorescence excitation-emission matrix spectrophotometry). $\mathrm{UV}_{254}$ absorbance analysis was performed using a Biochrom Libra S12 spectrophotometer at a wavelength of $254 \mathrm{~nm}$. Fluorescence analyses were conducted using a Cary Eclipse spectrophotometer with a Peltier temperature controller to maintain a constant $20^{\circ} \mathrm{C}$ during operation. The excitation wavelength was scanned in 5 -nm increments from 200 to $400 \mathrm{~nm}$, and the emission intensity from 280 to $500 \mathrm{~nm}$. The recordings had a wavelength accuracy of $\pm 1.5 \mathrm{~nm}$, and a wavelength reproducibility of $\pm 0.2 \mathrm{~nm}$. A Raman peak intensity scan was conducted first for sample calibration, and fluorescence intensities recorded were subsequently corrected to a Raman value of 20 units. No instrument-specific corrections were carried out. All apparatus in contact with samples were rinsed with $0.1 \mathrm{M} \mathrm{HCl}$ and deionized water. Results were displayed in an excitation-emission matrix format (EEM), from which peak $\mathrm{T}$ intensity and peak $\mathrm{C}$ emission and intensity values were recorded. Peak $\mathrm{T}$ intensity is the dominant fluorescence when microbial activity is high and in waters dominated by anthropogenic OM inputs, and has been observed to correlate with biochemical oxygen demand (BOD) (Hudson et al. 2008). Peak T fluorescence has peaks occurring at an excitation wavelength of $280 \mathrm{~nm}$ and emission of $350 \mathrm{~nm}$. Peak C often correlates with dissolved organic matter concentration in river systems and is considered to derive from soil-derived natural organic matter and its microbially processed derivatives, with peaks occurring within a range of 300-340 nm excitation, 400-460 emission.

Samples for DOC quantification were analyzed using a PPM LABTOC ${ }^{\circledR}$ analyzer, with a range of $0.18-10 \mathrm{mg} \mathrm{L}^{-1} \mathrm{C}$. Samples were filtered through a $0.45-\mu \mathrm{m}$ membrane prior to analysis. Samples were first mixed with persulfate, and inorganic carbon was purged off as $\mathrm{CO}_{2}$. Samples were then swept by $\mathrm{N}_{2}$ carrier to an infrared detector to determine $\mathrm{CO}_{2}$ at a wavelength of $4.4 \mu \mathrm{m}$, which was then related to the concentration of total carbon in sample. Accuracy and repeatability are $\pm 2 \%$. The specific ultraviolet absorbance (SUVA), a measure of organic matter character, was calculated as the UV absorbance per g $\mathrm{C}$.

\section{RESULTS AND DISCUSSION}

Table 2 and Figure 1 present the results of carbon isotope analyses $\left({ }^{14} \mathrm{C},{ }^{13} \mathrm{C}\right)$ and DOC character. Table 2 confirms that DOC concentration and character were similar to that previously observed by Bieroza et al. (2009), with sites A and B having lower fluorescence peak C emission wavelengths than site $\mathrm{C}$, a greater proportion of peak $\mathrm{T}$ to peak $\mathrm{C}$ fluorescence, and less $\mathrm{UV}$ absorbance per $\mathrm{g}$ DOC, all indicators of less aromatic and less hydrophobic DOC (Baker et al. 2008). Figure 1 presents both ${ }^{14} \mathrm{C}$ and ${ }^{13} \mathrm{C}$ data for filtered, filtered and autoclaved, and filtered and boiled samples, respectively; also shown are $1 \sigma$ analytical uncertainty for ${ }^{14} \mathrm{C}$ measurements. Analyzing the filtered and unsterilized samples, distinct trends can be seen in the data, with decreasing ${ }^{14} \mathrm{C}$ with the residence time of the DOC at sites A and C, suggesting a processing of young and more labile carbon, leaving an older, more recalcitrant fraction. For both ${ }^{13} \mathrm{C}$ and ${ }^{14} \mathrm{C}$, it is apparent that both sterilization procedures introduce a greater uncertainty in the carbon isotopic composition. Table 2 shows that at only 1 site (C-LR) do the ${ }^{14} \mathrm{C}$ values overlap with the $1 \sigma$ analytical uncertainty, at 4 sites they overlap within $2 \sigma$ of the analytical uncertainty (C-RivD, C-D, A-RivW, B-USR), at 3 sites they fall within the $3 \sigma$ uncertainty (A-SHR, B-LSR, C-H), and 1 site falls outside the $3 \sigma$ uncertainty range (A-FR). ${ }^{13} \mathrm{C}$ values show substantial changes in composition with sterilization and a greater site dependency. At site C, except for site C-DR, the sterilized samples fall outside $3 \sigma$ of the quoted analytical precision $( \pm 0.1 \%$ ), but within $1 \%$ of the filtered sample composition. At sites $\mathrm{A}$ and $\mathrm{B}$, there 


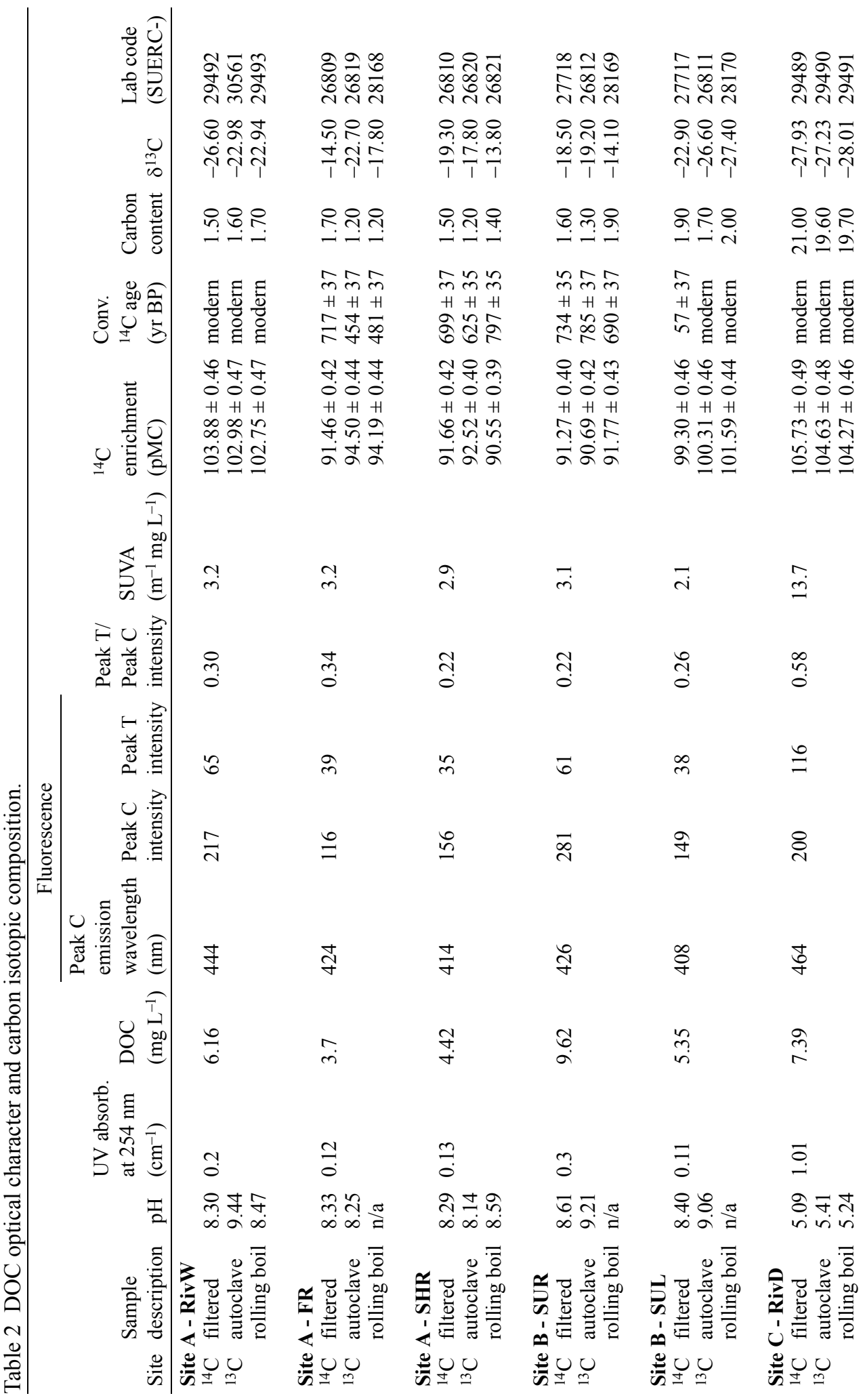




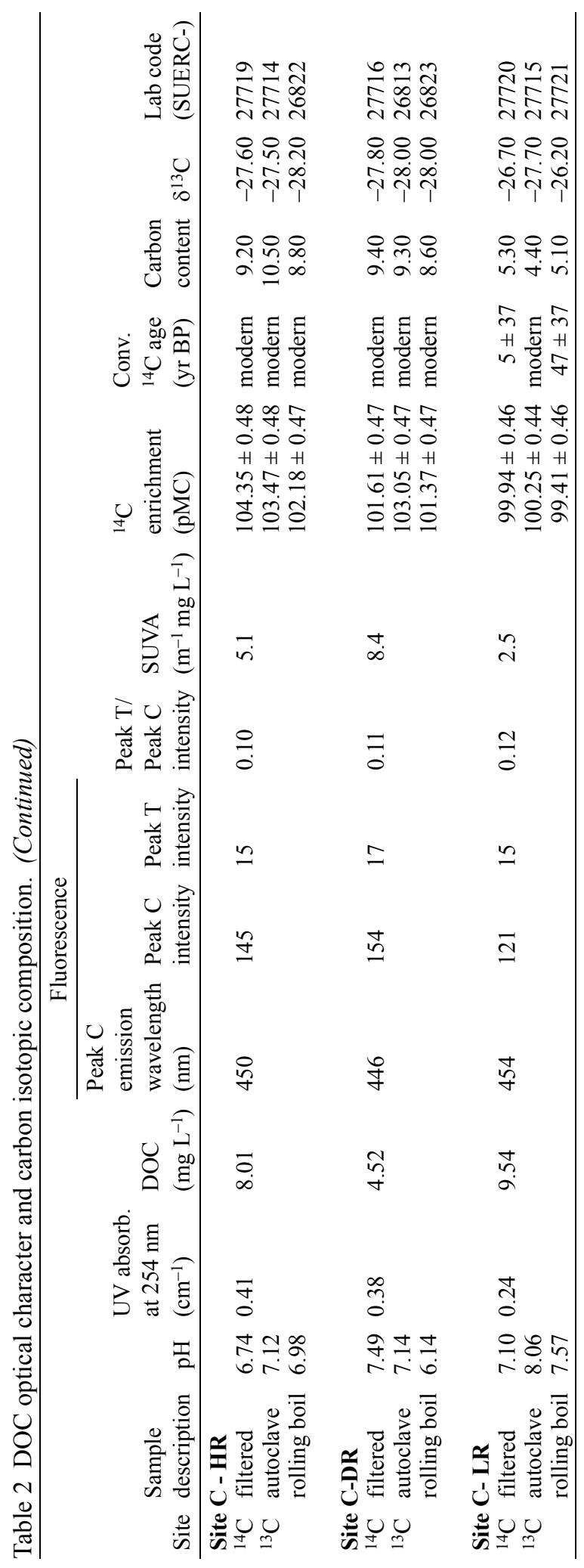


are up to $8 \%$ differences between the ${ }^{13} \mathrm{C}$ of filtered and sterilized samples and no overlap within $3 \sigma$ of the analytical uncertainty for any sample. There is no consistent relationship between sterilization methods, change in carbon isotopic composition, and the initial DOC concentration or character. Table 2 demonstrates that ${ }^{14} \mathrm{C}$ and ${ }^{13} \mathrm{C}$ can either increase or decrease with sterilization. With autoclaving, ${ }^{14} \mathrm{C}$ becomes more enriched in 5 of the 9 samples and with boiling, ${ }^{14} \mathrm{C}$ becomes depleted in 6 of out 9 samples. For ${ }^{13} \mathrm{C}, 5$ out of 9 samples are isotopically lighter after both autoclaving and boiling. This variability and lack of relationship with dissolved organic matter character might indicate that it is the fine colloidal $(<0.7 \mu \mathrm{m})$ fraction of DOC that is being affected by the sterilization procedure.

A

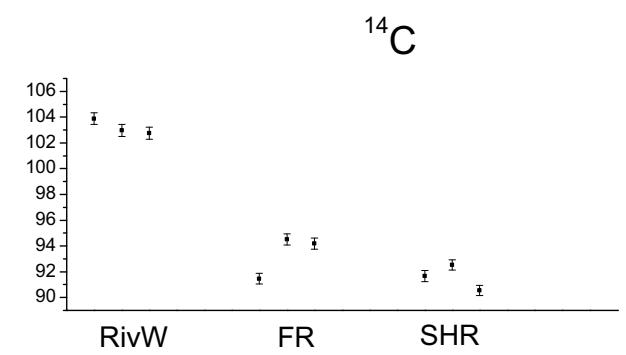

B
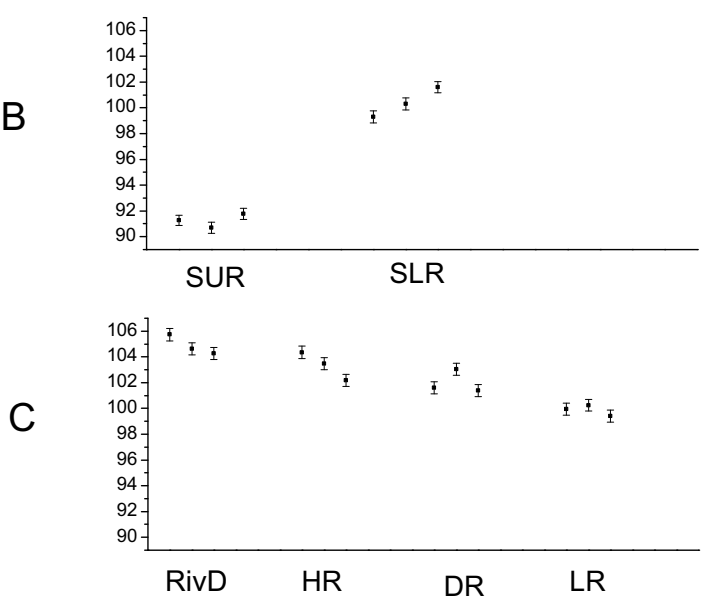
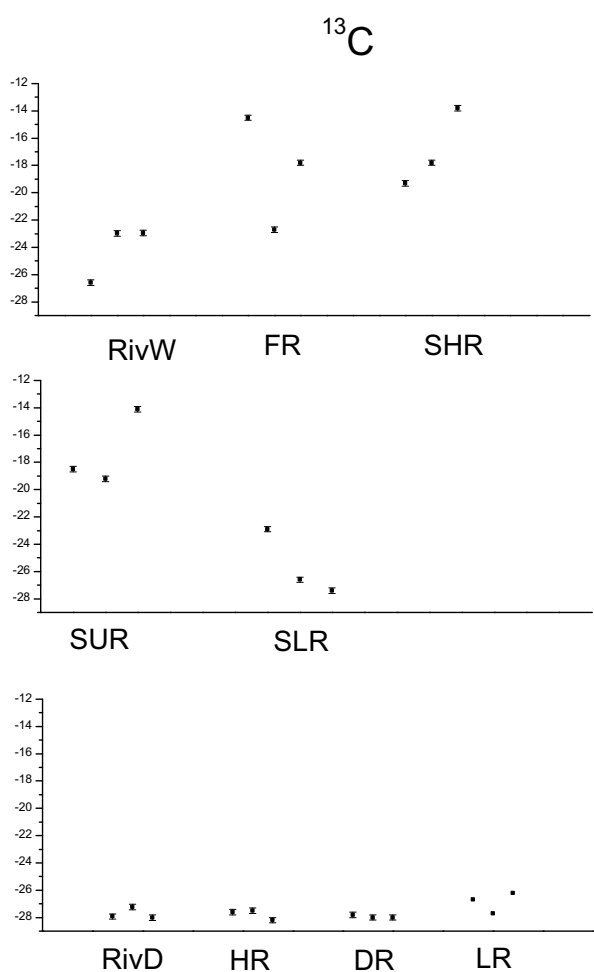

Figure 1 Comparison of ${ }^{14} \mathrm{C}$ and ${ }^{13} \mathrm{C}$ of DOC for sites $\mathrm{A}, \mathrm{B}$, and $\mathrm{C}$. At each site, the results are listed from upstream to downstream, and the 3 isotope data points are in the order filtered, filtered and autoclaved, and filtered and boiled.

\section{CONCLUSIONS}

Both sterilization methods increase the uncertainty associated with the ${ }^{14} \mathrm{C}$ and ${ }^{13} \mathrm{C}$ of dissolved organic carbon (DOC). ${ }^{14} \mathrm{C}$ and ${ }^{13} \mathrm{C}$ changes are not unidirectional, and are not related to either original DOC composition or sterilization technique used. Further research is necessary to investigate the processes taking place, but our initial hypothesis is that both sterilization procedures disrupt the previously stable fine colloidal fraction (Aiken et al. 2011) that passes through the $0.7-\mu \mathrm{m}$ filters, and depending on material present, permit the liberation and restabilization of different fractions of DOC.

Neither sterilization method is recommended unless essential. In cases where water is collected from sites where there are strong reasons for suspecting the presence of pathogenic organisms, we 
would recommend that a full assessment of the biological risk is carried out, once the risk level has been determined unsterilized samples should be processed using the appropriate level of containment based on the assessed risk (WHO 2004). Where these facilities do not exist and so samples must be sterilized, we recommend that a greater uncertainty should be placed on ${ }^{14} \mathrm{C}$ and ${ }^{13} \mathrm{C} \mathrm{com}$ position. From this study, we recommend a $3 \sigma$ uncertainty on ${ }^{14} \mathrm{C}$ and we do not consider the ${ }^{13} \mathrm{C}$ representative of the ${ }^{13} \mathrm{C}$ of the initial DOC.

\section{ACKNOWLEDGMENTS}

We would like to acknowledge analytical support from the Natural Environment Research Council through NRCF(E) allocation 1413.0410 and SevernTrent Water for funding and site access. We are also very appreciative of the reviewer comments on the manuscript.

\section{REFERENCES}

Aiken GR, Hsu-Kim H, Ryan JN. 2011. Influence of dissolved organic matter on the environmental fate of metals, nanoparticles, and colloids. Environmental Science and Technology 45(8):3196-201.

Aufdenkampe AK, Mayorga E, Raymond PA, Melack JM, Doney SC, Alin SR, Aalto RE, Yoo K. 2011. Riverine coupling of biogeochemical cycles between land, oceans, and atmosphere. Frontiers in Ecology and Environment 9(1):53-60.

Baker A, Tipping E, Thacker SA, Gondar D. 2008. Relating dissolved organic matter fluorescence and functional properties. Chemosphere 73(11):1765-72.

Battin TJ, Kaplan LA, Findlay S, Hopkinson CS, Marti E, Packman AI, Newbold JD, Sabater H. 2008. Biophysical controls on organic carbon fluxes in fluvial networks. Nature Geoscience 1:95-100.

Battin TJ, Luyssaert S, Kaplan LA, Aufdenkampe AK, Richter A, Tranvik LJ. 2009. The boundless carbon cycle. Nature Geoscience 2:598-600.

Bieroza M, Baker A, Bridgeman J. 2009. Relating freshwater organic matter fluorescence to organic carbon removal efficiency in drinking water treatment. Science of the Total Environment 407(5):1765-74.

Billett MF, Moore TR. 2008. Supersaturation and evasion of $\mathrm{CO}_{2}$ and $\mathrm{CH}_{4}$ in surface waters at Mer Bleue peatland, Canada. Hydrological Processes 22(12): 2044-54.

Billett MF, Garnett MH, Harvey F. 2007. UK peatland streams release old carbon dioxide to the atmosphere and young dissolved organic carbon to rivers. Geophysical Research Letters 34: L23401, doi:10.1029/ 2007 GL031797.

Cole JJ, Caraco NF. 2001. Carbon in catchments: connecting terrestrial carbon losses with aquatic metabolism. Marine and Freshwater Research 52(1):101-10.

Cole JJ, Prairie YT, Caraco NF, McDowell WH, Tranvik LJ, Striegl RG, Duarte CM, Kortelainen P, Downing JA, Middelburg JJ, Melack J. 2007. Plumbing the global carbon cycle: integrating inland waters into the terrestrial carbon budget. Ecosystems 10(1):17184.
Cory RM, McKnight DM, Chin Y-P, Miller P, Jaros CL. 2007. Chemical characteristics of fulvic acids from Arctic surface waters: microbial contributions and photochemical transformations. Journal of Geophysical Research 112: G045S51, doi:10.1029/ 2006JG000343.

Evans CD, Freeman C, Cork LG, Thomas DN, Reynolds B, Billett MF, Garnett MH, Norris D. 2007. Evidence against recent climate-induced destabilisation of soil carbon from ${ }^{14} \mathrm{C}$ analysis of riverine dissolved organic matter. Geophysical Research Letters 34: L07407, doi:10.1029/2007GL029431.

Freeman S, Bishop P, Bryant CL, Cook GT, Dougans A, Ertunç T, Fallick AE, Ganeshram RS, Maden C, Naysmith P, Schnabel C, Scott EM, Summerfield MA, Xu S. 2007. The SUERC AMS laboratory after 3 years. Nuclear Instruments and Methods in Physics Research B 259(1):66-70.

Freeman S, Cook GT, Dougans AB, Naysmith P, Wilkcen $\mathrm{KM}, \mathrm{Xu}$ S. 2010. Improved SSAMS performance. $\mathrm{Nu}$ clear Instruments and Methods in Physics Research B 268(7-8):715-7.

Gulliver P, Waldron S, Scott EM, Bryant CL. 2010. The effect of storage in the radiocarbon, stable carbon and nitrogen isotopic signatures and concentrations of riverine DOM. Radiocarbon 52(3):1113-22.

Hudson NJ, Baker A, Ward D, Brunsdon C, Reynolds DM, Carliell-Marquet C, Browning S. 2008. Can fluorescence spectrometry be used as a surrogate for the Biochemical Oxygen Demand (BOD) test in water quality assessment? An example from South West England. Science of the Total Environment 391(1):14958.

Hudson NJ, Baker A, Reynold DM, Carliell-Marquet CM, Ward D. 2009. Changes in freshwater organic matter fluorescence intensity with freezing/thawing and dehydration/ rehydration. Journal of Geophysical Research Biogeosciences 114: G00F08, doi:10.1029/ 2008JG000915.

Kalbitz K, Schwesig D, Rethemeyer J, Matzner E. 2005. Stabilization of dissolved organic matter by sorption 
to the mineral soil. Soil Biology and Biochemistry 37(7):1319-31.

Pollard PC, Ducklow H. 2011. Ultrahigh bacterial production in a eutrophic subtropical Australian river: Does viral lysis short-circuit the microbial loop? Limnology and Oceanography 56(3):1115-29.

Raymond PA, McClelland JW, Holmes RM, Zhulidov AV, Mull K, Peterson BJ, Striegl RG, Aiken GR, Gurtovaya TY. 2007. Flux and age of dissolved organic carbon exported to the Arctic Ocean: a carbon isotopic study of the five largest arctic rivers. Global Biogeochemical Cycles 21: GB4011, doi:10.1029/ 2007GB002934.

Roe J, Baker A, Bridgeman J. 2009. Relating organic matter character to trihalomethane formation potential: a data mining approach. Water Science and Technology: Water Supply 8(6):717-23.

Schwesig D, Göttlein A, Haumaier L, Blasek R, Ilgen G. 1999. Soil organic matter extraction using water at high temperature and elevated pressure (ASE) as compared to conventional methods. International Journal of Environmental Analytical Chemistry 73(4):253-68.
Spencer RGM, Pellerin BA, Bergamaschi BA, Downing BD, Kraus TEC, Smart DR, Dahlgren RA, Hernes PJ. 2007. Diurnal variability in riverine dissolved organic matter composition determined by in situ optical measurement in the San Joaquin River (California, USA). Hydrological Processes 21(23):3181-9.

Tipping E, Billett MF, Bryant CL, Buckingham S, Thacker SA. 2010. Sources and ages of dissolved organic matter in peatland streams: evidence from chemistry mixture modeling and radiocarbon data. Biogeochemistry 100(1-3):121-37.

Wilkinson KJ, Balnois E, Leppard GG, Buffle J. 1999. Characteristic features of the major components of freshwater colloidal organic matter revealed by transmission electron and atomic force microscopy. Colloids and Surfaces A: Physicochemical and Engineering Aspects 155(2-3):287-310.

World Health Organization [WHO]. 2004. Laboratory Biosafety Manual. 3rd edition. Geneva: WHO.

Worrall F, Burt TP. 2007. Trends in DOC concentration in Great Britain. Journal of Hydrology 346(3-4):81-91. 